\title{
Modulation of histamine release by fatty acids. A new in vitro model investigating adverse drug reactions in various species
}

\author{
Modulation de l'histaminolibération par les acides gras
}

\author{
M. ENNIS, W. LORENZ
}

Department of Theoretical Surgery, Centre for Operative Medicine I, Klinıkum der Phllipps-Universität Marburg, Baldinger Strasse, $D$-3550 Marburg, West Germany

\begin{abstract}
Histamine release caused by drugs and/or their solvents is a well known phenomenon. In this study, both in vivo (anaesthetized and conscious dogs) and in vitro (isolated rat peritoneal, human and guinea-pig lung mast cells) models were used. Cremophor E1 and six derivatives of 12-hydroxystearic acid were compared for their histamine releasing abilities. Although the three types of isolated mast cells responded similarly, histamine release being observed with DH (the diester of 12-hydroxystearic acid with polyethylene glycol), TN (12-hydroxystearic acid polymerized with ethylene oxide) and $\mathrm{ME}$ (the monoester of 12-hydroxystearic acid esterified with polyethylene glycol), the anaesthetized dog exhibited elevated blood histamine levels and clinical symptoms after administration of all the solubilizing agents, except TN and ME. The reasons for this discrepancy are not known. The addition of the drugs (Althesin or propanidid) to their solubilizing agents caused histamine release, which was not observed with the solubilizing agent alone. This is the first demonstration of an in vitro model, which copies the clinical situation, i.e. solvent does nothing but the solvent plus drug combination causes histamıne release and hence adverse reactions.
\end{abstract}

Adverse reactions to drugs used during anaesthesia and surgery are common. Although reported incidences vary considerably, using data obtained from 23 carefully controlled clinical trials, the following incidences were obtained: all reactions $20-30 \%$, systemic reactions $1-5 \%$ and life-threatening reactions $0.1-0.5 \%$ [8]. In many cases, these reactions appear to be caused not by the drug itself but by the combination of drug and solvent. For example, the hypnotic drug Althesin ${ }^{\circledR}$ was found to elevate plasma histamine levels and produce tachycardia and hypotension in volunteers but the solvent alone, cremophor E1, was without adverse effects [3,

Received October 12, 1984; accepted December 16, 1984
RÉSUMÉ : La lıbération d'histamine, due à des produits anesthésiques et/ou à leurs solvants, est un phénomène bien connu. Deux modèles ont été utilisés au cours de cette étude : l'un in vivo (chez le chien anesthésié ou éveillé), l'autre in vitro (sur des mastocytes 1solés de péritoine de rat, de poumon humain ou de cobaye). Les capacités histaminolibératrices du crémophor $\mathrm{E} 1$ et de six dérivés de l'acıde 12-hydroxystéarique ont été comparées. Quoique les trois types de mastocytes isolés aient réagi de façon analogue, l'histaminolibération étant observée avec le DH (diester de l'acide 12-hydroxystéarique + polyéthylène glycol), le TN (acide 12hydroxystéarique polymérnsé avec de l'oxyde d'éthylène) et le ME (monoester de l'acide 12-hydroxystéarique estérifié avec du polyéthylène glycol), le chien anesthésié présente un taux d'histamine élevé et des symptômes cliniques après administration de tous les agents solvants, sauf le TN et le ME. Les raisons de cette différence ne sont pas connues. L'adjonction d'Alfatésine ou de propanidide aux agents solvants entraîne une histaminolibération, qui n'était pas observée avec le solvant seul. Cette étude est le premier exemple d'un modèle in vitro, copiant la situation clinique : le solvant n'entraîne pas de réaction, mais l'adjonction de prodult à ce dernier provoque une histaminolibération et donc des effets secondaires.

9]. In studies using cats and dogs, however, this solvent alone produced elevation of whole blood and plasma histamine levels and alterations in haemodynamic parameters [10].

In order to reduce the number of adverse reactions, two approaches must be followed : 1) the investigation of the mechanisms of histamine release caused by the solvent or the solvent plus drug combination, 2) the development of less toxic solubilizing agents.

In this study, both in vivo and in vitro techniques have been used to investigate the histamine release caused by cremophor E1 and related compounds. 


\section{MATERIALS AND METHODS}

\section{Anaesthetized dog experiments}

Anaesthetized mongrel dogs (both sexes) were prepared as previously described [13]. Briefly the dogs were anaesthetized with pentobarbitone, two catheters were inserted and $20 \mathrm{~min}$ allowed to elapse for stabilization. Two blood samples were removed before drug administration (to provide basal histamine levels) and then 2, 5, 10, 15 and 30 min after drug administration. The solubilizing agent was given as an intravenous bolus $\left(0.1 \mathrm{ml} \cdot \mathrm{kg}^{-1}\right)$. Histamine was determined in whole blood using the combined fluorometric-fluoroenzymatic method [7].

\section{Conscious dog experiments}

Beagle dogs (12-18 months old, both sexes) with two indwelling catheters were used. The drug was administered (200 $\mathrm{mg} \cdot \mathrm{kg}^{-1}$ ) via a catheter in the jugular vein; blood sampling (via the cephalic vein catheter) was performed at $-5,-1,3,5$, 10,15 and $30 \mathrm{~min}$ after drug injection. Histamine was determined in plasma, using the combined fluorometric-fluoroenzymatic assay of LORENZ and coworkers [7].

\section{Isolated mast cells}

Mast cells were obtained from human lung [4], guinea-pig lung [2] and the peritoneal cavity of the rat [1] by previously described methods. Briefly the lung tissue was used as soon as possible after organ excision. The tissue was cut into pieces and washed thoroughly with Tyrode's-Hepes buffer; it was then chopped into $1 \mathrm{~mm}^{2}$ chunks using a Mclllwain tissue chopper and finally enzymatically dispersed for $90 \mathrm{~mm}$ at $37{ }^{\circ} \mathrm{C}$ using collagenase type 1 (Sigma) $(0.05 \%$ in Tyrode's-Hepes buffer containing bovine serum albumin $0.1 \%$ ). The tissue was then mechanically disrupted, filtered through gauze and the cells recovered by centrifugation. The cells were then washed twice with Tyrode'sHepes and then used as described below.

Rat peritoneal mast cells were obtained from female SpragueDawley rats. These animals were anaesthetized with ether and then killed by cervical dislocation and exanguination. Tyrode's-Hepes buffer plus heparin was injected into the peritoneal cavity, the abdomen was massaged for $90 \mathrm{~s}$ and the cells then removed. These cells were then washed (twice) and recovered by centrifugation. The cell suspensions were then used as described below.

The cell suspensions (to a final volume of $1 \mathrm{ml}$ ) were prewarmed for $5 \mathrm{~min}$ at $37^{\circ} \mathrm{C}$. The drug was added and histamine release allowed to proceed for $10 \mathrm{~min}$. The reactions were terminated by the addition of ice-cold buffer and the cells and supernatants separated by centrifugation.

Histamine was determined in both portions by the combined fluorometric-fluoroenzymatic assay [7]. The results are expressed as percentage histamine released, i.e. : \% histamine release $=$ histamine in supernatant/(histamine in supernatant + cells) $\times 100$. The spontaneous histamine release, i.e. the histamine release in the absence of any stimulus ( $\mathrm{ca} 5 \%$ ), has been subtracted from all results in this communication. Positive controls, included in each experimental run, used the calcium ionophore A $23187\left(10^{-6} \mathrm{M}\right)$ and resulted in the release of $c a 70 \%$ of the total histamine.

\section{Materials}

Cremophor E1 and six derivatives of 12-hydroxystearic acid were the seven solubilizing agents tested in this study (generously provided by BASF, Ludwigshafen, FRG). The six derivatives of 12-hydroxystearic acid (12-HSA) were as follows : TN (12-HSA polymerized with ethylene oxide; degree of polymerization 15 ; ANN. FR. ANESTH. RÉANIM., 2, 1985.
$15 \mathrm{EO}$ ), MO (ethoxylated monoglyceride of 12-HSA; $46 \mathrm{EO}$ ), ET (ethoxylated triglyceride of 12-HSA; $48 \mathrm{EO}$ ), DH (diester of 12-HSA esterified with polyethylene glycol 600; PEG), ED (ethoxylated diester of 12-HSA with PEG; $10 \mathrm{EO}$ ) and ME (monoester of 12-HSA esterified with PEG).

Preparations of Althesin and its solubilizer were provided by Glaxo; Bayer supplied the samples of propanidid and its solubilizer; the calcium ionophore A 23187 was purchased from Boehringer.

\section{RESULTS}

\section{Anaesthetized dog experiments}

In this model, all the solubilizing agents tested, with the exception of $\mathrm{TN}$ and ME, released clinically significant amounts of histamine $\left(>10 \mathrm{ng} \cdot \mathrm{ml}^{-1}\right.$ canine blood; data not shown). The careful examination of clinical symptoms and parameters such as redness, oedema, blood pressure changes, etc., confirmed these measurements.

\section{Conscious dog experiments}

TN (200 mg $\cdot \mathrm{kg}^{-1}$ ) was administered to the conscious beagles on four separate occasions (table I). Histamine release was reduced on the second application, but higher on the third occasion than on the first. The fourth application resulted in either an identical release to the first or a markedly higher release.

Table I. - Repeated application of TN in conscious beagles

\begin{tabular}{lcccc}
\hline & \multicolumn{4}{c}{$\begin{array}{c}\text { Maximum rise in plasma histamine content }\left(\mathrm{ng} \cdot \mathrm{ml}^{-1} \text { ) }\right. \\
\end{array}$} \\
& $\begin{array}{c}\text { Dog } 2801 \\
\text { Basal }\end{array}$ & After drug & Basal & After drug \\
\hline & & & & \\
Day 1 & 3.0 & 96.3 & 2.4 & 26.2 \\
Day 2 & 0.9 & 66.3 & 3.0 & 4.5 \\
Day 5 & 4.4 & 144.3 & 0.9 & 39.3 \\
Day 8 & 2.3 & 96.2 & 2.3 & 219.0 \\
\hline
\end{tabular}

\section{Isolated mast cell experiments}

In contrast to the results obtained with anaesthetized dogs, only three solubilizing agents released histamine from the three mast cell preparations (human lung, guinea-pig lung and rat peritoneal mast cells). The three solubilizing agents which released histamine in a dose-dependent manner were TN, DH and ME. The results obtained with the human lung cells and the rat peritoneal mast cells are illustrated in figure 1, those obtained with guinea-pig lung cells being omitted for clarity. The maximal response to TN was $c a 22 \%$ (human lung), ca $38 \%$ (guinea-pig lung) and $c a 58 \%$ (rat peritoneal mast cells). DH produced ca $50 \%$ (rat peritoneal mast cells), ca $60 \%$ (human lung) and $c a$ 

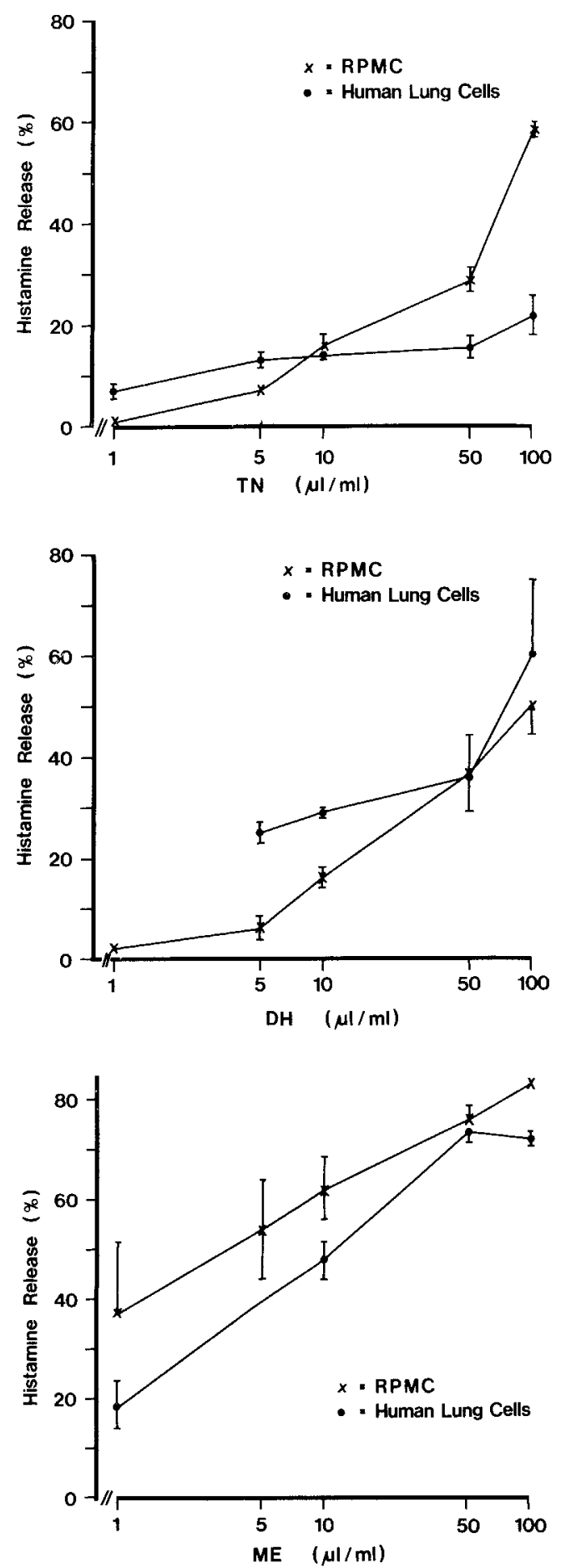

Fig. 1. - Histamine release induced by three solubilizing agents (TN, DH and ME) from rat peritoneal mast cells (RPMC) and human lung cells. All values are mean \pm SEM, for $n=3-4$ experiments.

$65 \%$ (guinea-pig lung). In all three cell types, ME produced near maximal histamine release (70-80\%).

The action of Althesin and propanidid and their solvents was examined using rat peritoneal mast cells
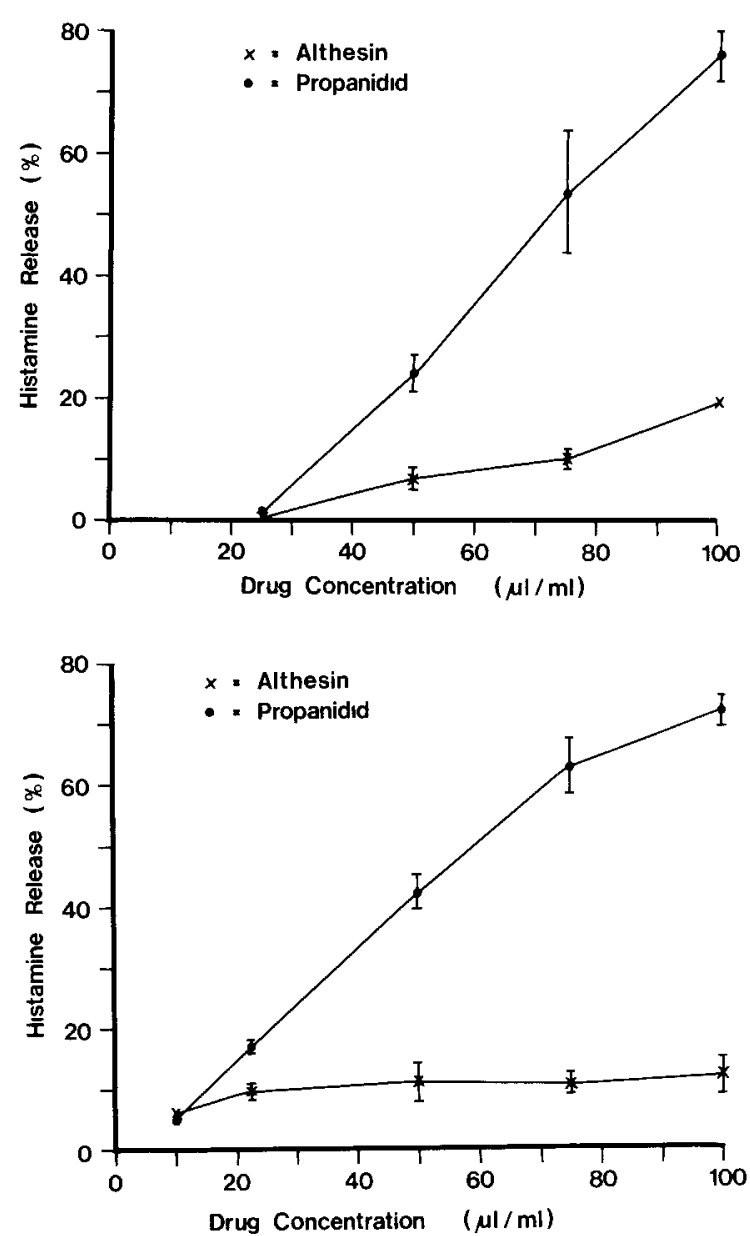

Fig. 2. - Histamine release induced by Althesin and propanidid from rat peritoneal mast cells (top panel) and guinea-pig lung cells (bottom panel). All values are mean \pm SEM, for $n=3-4$ experiments.

and guinea-pig lung cells (fig. 2). In both cases the solvent alone elicited no histamine release, but the drug plus solvent combination released histamine. In both cases propanidid was much more active.

\section{DISCUSSION}

There has been much work published on the histamine releasing ability of cremophor and its derivatives using in vivo models [11-13]. Cremophor E1, produced by the oxethylation of castor oil at elevated temperatures in an alkaline medium, is a mixture of hydrophilic and hydrophobic components [12]. In the anaesthetized dog model, the hydrophilic components did not release histamine. Of the hydrophobic components (composed of $80 \%$ derivatives of ricinoleic acid, $5 \%$ derivatives of oleic acid), only the derivatives of oleic acid released histamine [11]. Further experimentation indicated that the derivatives of 12-hydroxystearic acid were the least dangerous in this test system [13]. In the first part of the 
study here presented, cremophor E1 and six derivatives of 12-hydroxystearic acid were compared using two models : the anaesthetized dog and isolated mast cells. The results differed markedly in both systems. Only one compound (DH) was active in both test systems. Indeed the two substances exhibiting no activity in the anaesthetized dog model (TN, ME) were active in the isolated cell systems. It is interesting to note that the response to both $\mathrm{ME}$ and $\mathrm{DH}$ was similar in all three cell types examined; only the response to TN exhibited any major species difference. In previous studies investigating a wide range of histamine releasing agents, human and guinea-pig lung cells were much less reactive than the rat peritoneal mast cells $[2,4]$. The solubilizing agents have been further examined in rat peritoneal mast cells and the results indicated that the response obtained occurs via a cytolytic mechanism [6]. However, although cremophor E1 and TN have identical tenside and micelle-forming properties (Lang, personnal communication), the responses obtained were very different, cremophor being inactive and TN active in the cellular systems.

The results obtained using conscious beagles are the first examining the effect of this solubilizing agent on non-anaesthetized dogs. The dose used in these experiments was approximately double that in the anaesthetized dog studies. Adverse reactions to cremophor E1 were previously thought to fall into two categories : the dog model where the animal reacts on first exposure and the pig model where the animal reacts on second exposure [5]. In these experiments, although the dogs reacted on first exposure and had a reduced reaction on second exposure, the third exposure ( 5 days after the first) elicited a much greater response.

The data presented in the final part of the result section demonstrates the first evidence for a model which resembles the clinical situation. Mast cells from two species (rat and guinea-pig) did not respond to the solvent alone but only to the combination of drug plus solvent. In both species, the drug propanidid elicited the most histamine release.

In 1984, both Althesin and propanidid were removed from the market in many European countries; it might therefore be thought that research such as presented in this paper is no longer clinically relevant. However, many drugs are solubilized with the aid of cremophor, including steroid hormones, antibiotics, immunosuppressants and vitamins. In many other preparations, e.g. cosmetics, small amounts of cremophor are present. The mechanisms of histamine release that are currently being investigated include :

- A direct disruptive action on the mast cell surface : probably true for DH, TN and ME but not for cremophor itself, since this solvent alone does not produce histamine release from isolated cells;

- an immunological mechanism involving e.g. complement activation : a possible mechanism, since WAT-
KINS [14] found an involvement of complement in $81 \%$ of the adverse reactions to Althesin which he had investigated;

- a direct but selective action of the drug plus solvent combination on the mast cell surface : possible and under investigation.

Acknowledgements : This work was supported by a grant from the Deutsche Forschungsgemeinschaft (Lo 199/14-1). One of us (M.E.) wishes to thank the Alexander von Humboldt Stiftung for support. The authors would like to thank Professor RöHER (Head of Department of Surgery, Centre of Operative Medicine 1, Marburg) and Dr Hellwig (BASF, Ludwigshafen) for many useful discussions and their valuable support in carrying out the experimental procedures used in this study. We would also like to thank W. Gerland, B. KaPP, L. LÜbeN and A. Schmal for their technical assistance, and D. WEBER for preparing the figures.

\section{BIBLIOGRAPHY}

1. Atkinson A., Ennis M., Pearce F.L. The effect of alkaline earth cations on the release of histamine from rat peritoneal mast cells treated with compound $48 / 80$ and peptide $401 . \mathrm{Br} . J$. Pharmacol., 65 : 395-402, 1979.

2. Barrett K.E., Ennis M., Pearce F.L. Mast cells isolated from guinea-pig lung : characterization and studies on histamine secretion. Agents Actions, 13 : 122-126, 1984.

3. Doenicke A., Lorenz W., Beigl R., Bezecny H., Uhlig G., Kalmar L., Praetorius B., Mann G. Histamine release after intravenous application of short-actıng hypnotics. A comparison of etomidate, Althesin (CT 1341) and propanidid. Br. J. Anaesth., 45 : 1097-1104, 1973.

4. ENNIS M. Histamine release from human pulmonary mast cells. Agents Actions, 12: 60-63, 1982.

5. ENNIS M., LORENZ W. Hypersensitivity reactions induced by anaesthetics and plasma substitutes. In : Immunotoxicology, J.H. Dean ed. CRC Reviews, in press.

6. ENNis M., Lorenz W., KaPp B., LÜben L., Schmal A. A comparison of the histamine releasing activity of seven solubilizing agents in two models : the in vivo anaesthetized dog and in vitro rat peritoneal mast cells. Agents Actions, in press.

7. Lorenz W., Barth H., Thermann M., Schmal A., Dormann P., NiEMEyer I. Fluorometric histamıne determinations in canine plasma under normal conditions, following application of exogenous histamine and during histamine release by Haemaccel ${ }^{\circledR}$. Hoppe-Seyler's Z. Physiol. Chem., 355 : 1097-1111, 1974.

8. LoRenz W., Doenicke A. $\mathrm{H}_{1}-\mathrm{H}_{2}$ blockade : a prophylactic principle in anaesthesia and surgery against histamine release response of any degree of severity. N. Engl. J. Allergy, in press.

9. Lorenz W., Doenicke A., Meyer R, Reimann H.J., Kusche J., Barth H., Geesing H., Hutzel M., WeissenBACHER B. An improved method for the determination of histamine release in man: its application in studies with propanidid and thiopentone. Eur. J. Pharmacol., 19 : 180$190,1972$.

10. Lorenz W., Meyer R., Schmal A., Reimann H.J., Hutzel M., Werle E. On the species specificity of the histamine release from mast cell stores by cremophor E1. Naunyn-Schmiedeberg's Arch. Pharmak., 269: 417, 1971. 
11. Lorenz W., Reimann H.J., Schmal A., Dormann B., Schwarz B., Neugebauer E. Histamine release in dogs by cremophor E1 and its derivatives : oxethylated oleic acid is the most effective constituent. Agents Actions, $7: 63-67$, 1977.

12. Lorenz W., Reimann H.J., Schmal A., Tauber R., Uhlig $R$. Histamine release from typical and atypical mast cell stores by cremophor E1. Naunyn-Schmiedeberg's Arch. Pharmak. (Suppl.), 274 : R75, 1972.

13. Lorenz W., Schmal A., Schult H., Lang S., Ohman C.,
Weber D., KapP B., Lüben L., Doenicke A. Histamine release and hypotensive reactions in dogs by solubilizing agents and fatty acids : analysis of various components in cremophor E1 and development of a compound with reduced toxicity. Agents Actions, $12: 64-80,1982$.

14. WatKINS J. «Hypersensitivity response " to drugs and plasma substitutes used in anaesthesia and surgery (pp. 254291). In: Trauma, stress and immunity in anaesthesia and surgery. J. Watkins and M. Satto eds. Butterworths, London, 1982.

The influence of $\mathrm{H}_{2}$ receptor antagonists on the plasma concentrations of midazolam and temazepam. - P. Elliott, J.W. Dundee, R.J. Elwood, P.S. Collier. Eur. J. Anaesthesiol., 1: 245-251, 1984.

Chez des volontarres sains, a été étudié l'effet d'une prémédication de $24 \mathrm{~h}$ avec $450 \mathrm{mg}$ de ranitidine et $1200 \mathrm{mg}$ de cimétidine, en comparant avec du placebo sur les niveaux plasmatiques de deux benzodiazépines administrées oralement en une prise unique : $15 \mathrm{mg}$ de mıdazolam (rapport d'extraction hépatique élevé) ou $20 \mathrm{mg}$ de témazépam (rapport d'extraction hépatique bas). La concentration plasmatique du midazolam est significativement supérieure après ranitidine ou cimétidine par comparaison avec le placebo; la concentration plasmatique du témazépam n'est nullement affectée par la prémédication. La mesure des paramètres pharmacocinétiques montre que ranitidine et cimétidine augmentent d'environ $70 \%$ la biodisponibilité du midazolam, alors que celle du témazépam n'est pas modifiée.

Ces résultats suggèrent que ranitidine et cimétidıne affectent le fonctionnement hépatique. II étart déjà connu que ces deux antagonistes des récepteurs $\mathrm{H}_{2}$ réduisaient le débıt sanguin hépatique et que la cimétidine interférait avec le métabolisme hépatique des substances par l'intermédiaire de sa structure imidazole réagissant avec le cytochrome $P_{450}$. Or la ranitidine, ne possédant pas une telle structure, n'aurait pas d'effet sur le système enzymatique microsomal. Ces notions sont actuellement controversées et il semblerait que la ranitidıne puisse se lier avec ce système enzymatique, expliquant l'augmentation des concentrations plasmatiques et de la demi-vie d'élimination des substances à métabolisme hépatique.

La prémédication anesthésique à visée antihistaminique par un anti- $\mathrm{H}_{2}$ risque donc de modifier la durée d'action des substances à métabolisme hépatique utilisées pour l'anesthésie.

M.C. LAXenAiRe. 